\title{
Effect of Chewing Xylitol Gum on Salivary Volume and Acidity
}

\author{
Alfonsa Angwarmase*, Fen Tih**, Meilinah Hidayat*** \\ * Faculty of Medicine Maranatha Christian University \\ **Biochemistry Department Faculty of Medicine Maranatha Christian University \\ *** Nutritional Department Faculty of Medicine Maranatha Christian University \\ Jalan Prof. drg. Suria Sumantri MPH No. 65 Bandung 40164 Indonesia \\ Email:fentihfk@gmail.com
}

\begin{abstract}
Dental caries or tooth decay is a result of the production of acid from fermentation of bacteria that destroy tooth tissue. It can be prevented by maintaining the stability of salivary volume and acidity. Chewing xylitol gum is beneficial for increasing salivary volume and acidity. The aim of the study is to determine the effect of chewing xylitol gum on salivary volume and acidity. The study is a quasi experiment conducted to 30 males aged between 17-25 years old. Pre and post treatment's salivary volume are measured with measuring cup. Pre and post treatment's salivary acidity are measured using a pHmeter with 0,1 accuracy. Data are analyzed with paired " $t$ " test $(a=0,05)$. Average salivary volume after chewing xylitol gum increased very significantly from $0,26 \mathrm{~mL}$ to $13,37 \mathrm{~mL}(p=0,000)$. Average salivary acidity after chewing xylitol gum increased very significantyly from 6,47 to $7,36(p=0,000)$. The research concludes that chewing xylitol gum increases salivary volume and acidity.
\end{abstract}

Keywords : dental caries, xylitol, salivary volume, salivary acidity 


\title{
Pengaruh Mengunyah Permen Karet yang Mengandung Xylitol terhadap Volume dan Keasaman Air Liur
}

\author{
Alfonsa Angwarmase*, Fen Tih**, Meilinah Hidayat*** \\ *Fakultas Kedokteran Universitas Kristen Maranatha \\ **Bagian Biokimia Fakultas Kedokteran Universitas Kristen Maranatha \\ ***Bagian Nutrisi Universitas Kristen Maranatha \\ Jalan Prof. Drg. Suria Sumantri MPH No.65 Bandung 40164 Indonesia \\ Email: fentihfk@gmail.com
}

\begin{abstract}
Abstrak
Karies dentis atau gigi berlubang terjadi akibat produksi asam dari proses fermentasi bakteri. Hal tersebut dapat dicegah dengan menjaga kestabilan volume dan keasaman saliva. Mengunyah permen karet yang mengandung xylitol bermanfaat untuk meningkatkan volume dan $\mathrm{pH}$ saliva. Penelitian ini bertujuan untuk mengetahui pengaruh pemberian permen karet yang mengandung xylitol terhadap volume dan $\mathrm{pH}$ saliva. Penelitian ini merupakan eksperimental semu dengan subjek penelitian berjumlah 30 orang laki-laki dengan rentang usia 17-25 tahun. Volume saliva sebelum dan sesudah perlakuan diukur menggunakan gelas ukur. $\mathrm{pH}$ saliva sebelum dan sesudah perlakuan diukur menggunakan $\mathrm{pH}$ meter digital dengan akurasi 0,1 . Analisis data menggunakan uji " $t$ " berpasangan dengan $\alpha=0,05$. Hasil penelitian menunjukkan rerata volume saliva sesudah mengunyah permen karet yang mengandung xylitol meningkat dengan sangat signifikan dari $0,26 \mathrm{~mL}$ menjadi $13,37 \mathrm{~mL}(\mathrm{p}=0,000)$. Rerata $\mathrm{pH}$ saliva sesudah mengunyah permen karet yang mengandung xylitol meningkat dengan sangat signifikan dari 6,47 menjadi 7,36 ( $\mathrm{p}=0,000)$. Simpulan penelitian ini adalah permen karet yang mengandung xylitol dapat meningkatkan volume dan $\mathrm{pH}$ saliva.
\end{abstract}

Kata kunci: karies dentis, xylitol, volume saliva, keasaman saliva 


\section{Pendahuluan}

Penyakit gigi dan mulut merupakan penyakit masyarakat yang dapat menyerang semua golongan umur yang bersifat progresif dan akumulatif. Hasil studi morbiditas SKRT-Surkesnas 2001 menunjukkan dari prevalensi 10 (sepuluh) kelompok penyakit yang dikeluhkan masyarakat, penyakit gigi dan mulut menduduki urutan pertama dengan angka prevalensi $61 \%$ penduduk, dengan persentase tertinggi pada golongan umur lebih dari 55 tahun (92\%). Penyakit gigi dan mulut yang terbanyak dialami masyarakat di Indonesia adalah karies gigi dan penyakit periodontal. ${ }^{1}$ Menurut Riset Kesehatan Dasar Kementrian Kesehatan Republik Indonesia (RISKESDAS) tahun 2013, jumlah kerusakan gigi penduduk adalah 460 gigi per 100 orang. Karies gigi ditandai dengan adanya satu atau lebih kerusakan pada gigi, hilangnya gigi akibat karies, atau terdapat lapisan plak pada permukaaan gigi. Sekitar 60\%-90\% anak usia sekolah di dunia mengalami karies dan prevalensinya lebih tinggi pada keluarga dengan status sosioekonomi rendah yang sering mengabaikan layanan pencegahan dan penanganan karies. ${ }^{2}$

Karies gigi merupakan suatu penyakit jaringan keras gigi, yaitu email, dentin, dan cementum, yang disebabkan oleh aktivitas metabolisme mikroorganisme yang mengakibatkan terjadinya proses demineralisasi jaringan keras gigi. Karies gigi adalah penyakit multifaktorial, meliputi faktor utama yaitu gigi, saliva, mikroorganisme, karbohidrat dari makanan, dan waktu. Karies gigi juga dipengaruhi oleh faktor luar seperti umur, jenis kelamin, pendidikan, sosial ekonomi, lingkungan, sikap, dan perilaku yang berhubungan dengan kesehatan gigi. ${ }^{3,4}$

Karies gigi yang tidak ditangani dapat menyebabkan seseorang kehilangan giginya sehingga menyebabkan masalah bicara dan tidur. Kesehatan gigi dan mulut merupakan investasi seumur hidup, karena itu pencegahan karies merupakan hal yang sangat penting.Menjaga kebersihan mulut adalah cara terbaik untuk mencegah terjadinya penyakit-penyakit dalam mulut, seperti: karies gigi dan radang gusi. ${ }^{2,5}$

Dalam dekade terakhir banyak dilakukan, penelitian mengenai penggunaan suplemen fluor dan xylitol dalam mencegah karies gigi. Beberapa penelitian telah mengkaji manfaat pemberian suplemen fluor dalam bentuk tablet, permen karet, atau drop dalam pencegahan karies pada anak. Hasilnya menunjukkan bahwa manfaat pemberian suplemen fluor terhadap pencegahan karies masih kontroversi. Penggunaan xylitol dalam pencegahan karies juga masih kontroversi. Banyak organisasi kesehatan di dunia mendukung rekomendasi penggunaan xylitol pada populasi yang mempunyai risiko karies gigi. Namun demikian sebagian besar ahli menyatakan masih diperlukan penelitian dengan desain yang baik untuk membuktikan manfaat xylitol dalam pencegahan karies. ${ }^{2}$ 
Ada beberapa cara untuk menjaga kesehatan gigi dan mulut. Salah satunya adalah menggunakan pendekatan yang sering dan mudah dilakukan oleh masyarakat, seperti mengunyah permen karet. ${ }^{6}$ Mengunyah permen karet merupakan stimulus rasa/gustatori dan mekanis yang meningkatkan aliran saliva. Proses mengunyah merangsang produksi air liur/ saliva dan mengubah komposisi saliva sehingga konsentrasi bikarbonat, fosfat, dan kalsium meningkat. Perubahan ini mencegah turunnya $\mathrm{pH}$ dan meningkatkan pembentukan kristal hidroksiapatit. Peningkatan volume saliva dapat membersihkan gula dan asam pada gigi. Mengunyah permen karet meningkatkan sekresi saliva, sehingga dapat digunakan untuk mengatasi mulut kering dan menjaga kesehatan rongga mulut. ${ }^{7,8}$

Banyak orang tidak mau mengonsumsi permen karet karena khawatir akan merusak gigi akibat kandungan gula sukrosa. Permen karet yang bebas gula, misalnya yang mengandung xylitol, adalah cara yang praktis untuk merangsang produksi saliva setelah mengonsumsi makanan yang mengandung gula. ${ }^{6}$ Berbeda dengan sukrosa, xylitol tidak dapat dimetabolisme oleh bakteri mulut dan dapat diklasifikasikan sebagai bahan nonkariogenik. ${ }^{8}$

Xylitol adalah polialkohol berkarbon lima yang secara bebas dapat ditemui di alam. Banyak buah dan tanaman yang mengandung xylitol, misalnya stoberi, raspberi, kol, dan sebagainya. ${ }^{7}$ Xylitol dipercaya memiliki efek antikaries dan dapat mengurangi insidensi karies sebesar 30-65\%. Efek anti karies ini berhubungan dengan efek xylitol terhadap volume dan $\mathrm{pH}$ saliva. ${ }^{10}$

Penelitian ini bertujuan untuk membuktikan pengaruh mengunyah permen karet yang mengandung xylitol terhadap volume dan $\mathrm{pH}$ saliva, yang kemudian dapat dimanfaatkan untuk menghindari gangguan kesehatan gigi dan mulut.

\section{Metode}

Penelitian ini adalah eksperimental semu dengan rancangan sebelum (pre test ) dan sesudah (post test). Subjek penelitian berjumlah 30 orang laki-laki berusia 17-25 tahun yang telah mendapat penjelasan dan menandatangani informed consent. Subjek penelitian tidak memiliki penyakit sistemik, mengonsumsi obat yang mempengaruhi sekresi saliva dalam satu bulan terakhir, memiliki gangguan pada kelenjar saliva, merokok, mengonsumsi produk tembakau, dalam keadaan dehidrasi, atau sedang dalam proses terapi radiasi kepala dan leher.

Alat-alat yang digunakan adalah pipet, gelas ukur, dan $\mathrm{pH}$ meter digital dengan akurasi 0,1 . Bahan penelitian yang digunakan adalah permen karet (1,45 gram per butir) bebas gula yang mengandung xylitol sebanyak $1119 \mathrm{mg} /$ butir. 
Minimal 60 menit sesudah makan dan minum, subjek penelitian diminta mengeluarkan saliva dengan cara meludah ke dalam gelas ukur yang kosong. ${ }^{10,11}$ Saliva dipindahkan ke wadah lain untuk pengukuran $\mathrm{pH}$ dengan $\mathrm{pH}$ meter. Volume $(\mathrm{mL})$ dan $\mathrm{pH}$ saliva tiap subjek penelitian dicatat sebagai hasil pre test. Tiap subjek penelitian diberi 2 butir permen karet untuk dikunyah selama 5 menit. Setelah permen karet dikeluarkan dari mulut, dilakukan pengukuran volume dan $\mathrm{pH}$ saliva ulang dan dicatat sebagai hasil post test.

Data yang diperoleh berupa volume $(\mathrm{mL})$ dan $\mathrm{pH}$ saliva sebelum dan sesudah perlakuan dibandingkan menggunakan uji t berpasangan dengan $\alpha=0,05$.

\section{Hasil}

Volume saliva meningkat setelah mengunyah permen karet yang mengandung xylitol, dari 0,1-1,4 mL dengan rerata $0,26 \mathrm{~mL}$ menjadi antara 1,6-24,2 $\mathrm{mL}$ dengan rerata $13,37 \mathrm{~mL}$. Pengukuran pH saliva menunjukkan peningkatan. pH saliva yang awalnya 4,8-7,44 dengan rerata 6,47 meningkat menjadi 6,88-7,99 dengan rerata 7,36.

\section{Tabel 1 Rerata Volume dan pH Saliva Sebelum dan Sesudah Mengunyah Permen Karet yang Mengandung Xylitol}

\begin{tabular}{cccc}
\hline & & Rerata & $\mathrm{p}$ \\
\hline \multirow{2}{*}{ Volume } & Sebelum & $0,26 \mathrm{~mL}$ & \multirow{2}{*}{$0,000^{* *}$} \\
\cline { 2 - 3 } & Sesudah & $13,37 \mathrm{~mL}$ & \\
\hline \multirow{2}{*}{$\mathrm{pH}$} & Sebelum & 6,47 & \multirow{2}{*}{$0,000^{* *}$} \\
\cline { 2 - 3 } & Sesudah & 7,36 & \\
\hline
\end{tabular}

Analisis statistik dengan uji $\mathrm{t}$ berpasangan menunjukkan nilai $\mathrm{p}<0,01$ yang berarti terdapat peningkatan yang sangat bermakna dari volume dan $\mathrm{pH}$ saliva sebelum dan sesudah mengunyah permen karet yang mengandung xylitol.

\section{Diskusi}

Hasil penelitian ini sesuai dengan beberapa penelitian yang telah dilakukan sebelumnya. Penelitian Ni Nyoman Gemini Sari yang melibatkan 70 orang laki-laki perokok aktif menunjukkan terjadi peningkatan $\mathrm{pH}$ saliva setelah subjek penelitian mengunyah permen karet yang mengandung xylitol. ${ }^{12}$ Penelitian Sanjyot Mulay dan Hansa Jain menunjukkan hasil peningkatan $\mathrm{pH}$ saliva pada orang yang mengunyah permen karet yang mengandung xylitol selama 5 menit dibandingkan dengan orang yang mengunyah paraffin. ${ }^{13}$

Penelitian Wang (2012) menunjukkan terjadi peningkatan volume saliva yang sangat signifikan setelah mengunyah permen karet. Penelitian ini mengikutsertakan laki-laki dan 
perempuan berusia 18-65 tahun. ${ }^{5}$ Penelitian oleh Yuswir (2014) melibatkan lansia berusia 60-70 tahun juga menunjukkan peningkatan curah saliva setelah mengunyah permen karet yang mengandung xylitol tiga kali sehari setelah makan selama seminggu. Curah saliva yang tinggi meningkatkan volume dan $\mathrm{pH} .{ }^{14}$

Peningkatan volume dan $\mathrm{pH}$ saliva ini berguna untuk mengatasi xerostomia yang banyak dialami oleh masyarakat. Sebagian besar bakteri streptococcus dalam rongga mulut dan bakteri lainnya tidak dapat memfermentasi xylitol. Xylitol juga memiliki efek bakteriostatik pada streptococcus mutans. Mikroorganisme rongga mulut cenderung memilih senyawa dengan 6 atom karbon untuk dimetabolisme sebagai sumber energi, sedangkan xylitol memiliki 5 atom karbon $\left(\mathrm{C}_{5} \mathrm{H}_{12} \mathrm{O}_{5}\right)$.

Proses terjadinya karies gigi dimulai dengan adanya plaque di permukaan gigi. Sukrosa (gula) dari sisa makanan dan bakteri menyebabkan pembentukan asam laktat yang akan menurunkan $\mathrm{pH}$ mulut menjadi kritis $(5,5)$, akibatnya terjadi demineralisasi email yang berlanjut menjadi karies gigi. Penurunan $\mathrm{pH}$ dalam rongga mulut menjadi lebih lama setelah mengunyah permen karet mengandung xylitol karena xylitol menstabilkan kalsium dan fosfat di dalam saliva. Xylitol diserap dengan lambat sehingga demineralisasi tidak terjadi dan proses karies dapat dicegah. ${ }^{2,15}$

Xylitol berpengaruh terhadap kualitas dan kuantitas saliva. Xylitol membantu remineralisasi enamel gigi, mengurangi jumlah plak, mereduksi jumlah, transmisi, dan virulensi Streptococcus mutans, serta mereduksi adhesi flora pada plak. ${ }^{16}$

Peningkatan volume saliva membantu menjaga kesehatan rongga mulut. Saliva membasahi dan melindungi mukosa rongga mulut. Kandungan bikarbonat dalam saliva menetralkan asam di makanan serta asam yang dihasilkan bakteri di mulut, sehingga membantu mencegah karies dentis. Saliva juga memiliki aktivitas anti bakteri karena mengandung lisozim dan immunoglobulin A (IgA), IgG, IgM yang mencegah kolonisasi mikroorganisme dalam rongga mulut. Enzim laktoperoksidase dari sel asinus parotis dan submandibula dapat menghambat pertukaran zat dan pertumbuhan bakteri. Protein laktoferin menghambat pertumbuhan Candida albicans dan Eschericia coli. ${ }^{1,4}$

Kesehatan gigi dan mulut dapat ditingkatkan jika diikuti dengan perawatan kesehatan gigi dan mulut yang tepat, seperti rajin menggosok gigi di waktu dan dengan cara yang tepat dan konsultasi ke dokter gigi secara berkala. Langkah-langkah tersebut dapat dijadikan tindakan preventif terhadap karies dentis. ${ }^{2}$ 


\section{Research Article}

\section{Simpulan}

Mengunyah permen karet yang mengandung xylitol meningkatkan volume dan $\mathrm{pH}$ saliva.

\section{Daftar Pustaka}

1. Kementerian Kesehatan Republik Indonesia. Pedoman Usaha Kesehatan Gigi Sekolah. Jakarta:Kemenkes RI:2012.

2. Hendarto A. Nutrisi dan kesehatan gigi-mulut pada anak. Sari Pediatri 2015;17(1)

3. Tjahja IN, Sintawati FX, Yovita TA. Gambaran karies gigi permanen di beberapa puskesmas kota dan kabupaten Bandung, Sukabumi serta Bogor tahun 2002. Media Litbang Kesehatan. 2006;16(4):26-31.

4. Houwink DB, Winchel C. Ilmu kedokteran gigi pencegahan. Gadjah Mada University Press. Yogyakarta. 2000.

5. Wang, X. P. et al. History of frequent gum chewing is associated with higher unstimulated salivary flow rate and lower caries severity in healthy chinese adult. Caries Res. 2012;46: 513-18.

6. Qasim AA, Chaloob EK. Physicochemical characteristics of unstimulated and stimulated saliva with different chewing gum stimulation. J Baghdad College Den. 2012;24(2):94-98.

7. Holgerson, P.L. Xylitol and it's effect on oral ecology. Departement of odontology. Paediatric. Dentistry Faculty of Medicine UMEA. 2007:p16-20.

8. Karami-Nogourani M, Kowsari-Isfahan R, Hosseini-Behesti M. The effect of chewing gum's flavor on salivary flow rate and pH. Den Res J .2011;8:71-5.

9. Van Loveren C. Sugar alcohols: what is the evidence for caries-preventive and caries-therapeutic effects? Caries Res. 2004;38(3): 286-93.

10. Castila MFV, Carrasco CGN. Effect of xylitol chewing gum on dental plaque, saliva flow and saliva buffer capacity in chilean youngsters. Int. J. Odontostomat. 2013;7(1): 133-7.

11. Llop, RMFF. Jimeno G, Acien RMA, Dalmau LJB. Effects of xylitol chewing gum on salivary flow rate, ph, buffering capacity and presence of streptococcus mutans in saliva. Eur J Ped Dent. 2010;11(2)

12. Sari NNG. Permen karet xylitol selama lima menit meningkatkan dan mempertahankan pH saliva perokok selama tiga jam. Tesis: Program studi ilmu biomedik Program Pascasarjana Biomedik Universitas Udayana. Denpasar. 2011.

13. Mulay S, Jain $\mathrm{H}$. Change in salivary parameters: flow and $\mathrm{pH}$ after chewing xylitol and sorbitol chewing gums. Arch Oral Sci Res. 2014; 4(1):38-49.

14. Yuswir ARR. Pengaruh pemberian permen karet yang mengandung xylitol terhadap curah dan $\mathrm{pH}$ saliva pada lansia penderita diabetes mellitus tipe 2. Universitas Diponegoro:2014.

15. Makinen KK. Physical, chemical, and histologic changes in dentin caries lesions of primary teeth induced by regular use of polyol chewing gums. Acta Odontol Scand. 1998:56:148.

16. Maguire A, Rugg-Gunn AJ. Xylitol and caries prevention - is it magic bullet? BDJ. 2003;194(8):432. 